\title{
原著
}

$$
\begin{gathered}
\text { メニエール病の聴力予後に影響する因子の検討 } \\
\text { 岸野 明洋 鴫原俊太郎 野村 泰之 大島 猛史 } \\
\text { 日本大学医学部耳鼻咽喉・頭頸部外科学分野 }
\end{gathered}
$$

\section{The Hearing Level-Influencing Factors of Meniere's Disease}

\author{
Akihiro Kishino, Shuntaro Shiginara, Yasuyuki Nomura and Takeshi Oshima \\ Department of Otolaryngology-Head and Neck Surgery, Nihon University School of Medicine
}

\begin{abstract}
Objective: To investigate the factors that influence the hearing level in Meniere's disease patients.
Materials and methods: A retrospective study was conducted using the medical records of 60 patients with Meniere's disease who were treated in our hospital between January 2004 and December 2015.

Results: The study population was $35.0 \%$ male and $65.0 \%$ female. The average age of the patients was 50.5 (range 20-74) years old. The age distribution showed a peak at 40 years. The patients who were treated for more than 2000 days showed significantly increased hearing thresholds compared with those of the patients who were treated for less than 500 days. The patients with vertigo or dizziness showed significantly worsened hearing levels in comparison to those of the patients without these symptoms. Furthermore, the hearing level of the patients treated with a selective serotonin reuptake inhibitor (SSRI) or ventilation tubes worsened significantly more than that of the patients without these treatments.
\end{abstract}

Conclusion: This study revealed that 1) long-standing disease, 2) vertigo or dizziness and 3) treatment with SSRIs or 4) ventilation tubes are important predictors of the hearing level of Meniere's disease patients.

Key words: Meniere's disease, progress of hearing loss, vertigo, SSRI, ventilation tube メニエール病, 難聴の進行, めまい, 選択的セロトニン再取り込み阻害薬, 鼓膜換気チューブ

(J. Nihon Univ. Med. Ass., 2020; 79 (3): 125-132)

\section{はじめに}

メニエール病は難聴，耳鳴，耳閉感などの蝸牛症状を 伴うめまい発作を反復する疾患であり, 病期の進行によ り不可逆性の難聴の進行がみられることがある ${ }^{1)}$. 病初 期では発作時に変動する低音障害型の感音難聴を示し, その後発作を繰り返しながら病期が進行すると高音域が 障害され，さらに病期が進行すると全周波数に扔ける聴 力障害を示す ${ }^{21}$. 当科ではメニエール病症例に治療とし て薬剤投与とともに認知的アプローチと有酸素運動を含 めた生活指導を行っているが, 難聴のコントロールが困 難な症例が散見される。メニエール病による難聴・めま いの発作頻度や発症間隔，治療に対する反応は多様であ り, 聴力予後の予測は難しい. 聴力変化の指標となる要 因が明らかになれば，聴力予後を予測するうえでの有用 性は大きいと考える. 今回, 長期に経過観察し得たメ二 エール病症例に扔いて, 聴力の変化に影響する因子を後 ろ向き研究で検討した。

\section{対象と方法}

対象は 2004 年 2 月から 2015 年 5 月までに日本大学
医学部附属板橋病院耳鼻咽喉科を受診し, 300 日以上加 療したメニエール病症例 60 例（メニエール病確実例 41 例, メニエール病非定型例（蝸牛型）確実例 19 例）で ある。診断基準は, 日本めまい平衡医学会のめまいの診 断基準化のための資料 診断基準 2017 年改定を用いた ${ }^{3}$. 観察期間は 308 日から 6255 日に及び, 平均 1260.1 日, 中央值は 836 日であった。年齢は 20 歳〜 74 歳で平均 50.5 歳, 中央值 51.4 歳であった。男性 21 例 (29 72 歳, 平均 53.5 歳, 中央值 55.9 歳), 女性 39 例 $(20 \sim 74$ 歳, 平均 48.9 歳, 中央值 46.2 歳) であった。検討項目は年 代, 性別, 観察期間, ストレスの自覚の有無, めまい症 状の有無㧍よびめまい症状改善の有無, 各治療（漢方 薬, イソソルビド, 選択的セロトニン再取り込み阻害薬 (Selective serotonin reuptake inhibitor: SSRI), 抗不安薬, 鼓膜換気チューブ留置術）の有無が聴力予後に及ぼす 影響を検討した，聴力レベルの変化の評価は American Academy of Otolaryngology-Head and Neck Surgery (AAOHNS) のメニエール病の治療効果判定基準 ${ }^{4)}$ に準して, 各群に扔ける初診時と最終診察時の 4 分法 $(500,1000$, 2000, $4000 \mathrm{~Hz}$ ) の評価に加えて, 低音域と高音域の聴力 レベルの変化を評価するために低音域周波数 3 分法 $(125$, 
Table 1 Changes in auditory acuity

The changes in auditory acuity were assessed by subtracting the median auditory acuity at the last visit from that at the initial visit in each group.

\begin{tabular}{|c|c|c|c|c|c|}
\hline \multicolumn{2}{|c|}{$\begin{array}{l}\text { 低音域3周波数 (dB) } \\
(125,250,500 \mathrm{~Hz})\end{array}$} & \multicolumn{2}{|c|}{$\begin{array}{c}\text { 4分法 }(\mathrm{dB}) \\
(500,1000,2000,4000 \mathrm{~Hz})\end{array}$} & \multicolumn{2}{|c|}{$\begin{array}{c}\text { 高音域3周波数 (dB) } \\
(2000,4000,8000 \mathrm{~Hz})\end{array}$} \\
\hline 男性 & 女性 & 男性 & 女性 & 男性 & 女性 \\
\hline-6.7 & -6.7 & -1.3 & +1.3 & +1.7 & +3.3 \\
\hline \multicolumn{2}{|c|}{ ストレス自覚なしストレス自覚あり } & \multicolumn{2}{|c|}{ ストレス自覚なしストレス自覚あり } & \multicolumn{2}{|c|}{ |ストレス自覚なしストレス自覚あり } \\
\hline-0.8 & -7.5 & +3.1 & 0 & +3.3 & +1.7 \\
\hline $\begin{array}{l}\text { 非定型例 } \\
\text { (蝸牛型) }\end{array}$ & 確実例 & $\begin{array}{l}\text { 非定型例 } \\
\text { (蝸牛型) }\end{array}$ & 確実例 & $\begin{array}{l}\text { 非定型例 } \\
\text { (蜛牛型) }\end{array}$ & 確実例 \\
\hline-14.2 & -5 & -3.1 & +5 & 0 & +11.7 \\
\hline めまい改善なし & めまい改善あり & めまい改善なし & めまい改善あり & めまい改善なし & めまい改善あり \\
\hline+5.8 & -5 & +19.4 & +5 & +10.8 & +5 \\
\hline 漢方薬なし & 漢方薬あり & 漢方薬なし & 漢方薬あり & 漢方薬なし & 漢方薬あり \\
\hline-10 & -5 & -1.3 & +4.4 & 0 & +4.2 \\
\hline イソソルビドなし & イソソルビドあり & イソソルビドなし & イソソルビドあり & イソソルビドなし & イソソルビドあり \\
\hline-10 & -5 & -1.3 & +4.4 & 0 & +4.2 \\
\hline 抗不安薬なし & 抗不安薬あり & 抗不安薬なし & 抗不安薬あり & 抗不安薬なし & 抗不安薬あり \\
\hline-6.7 & -5.8 & -2.5 & +2.5 & +5 & +1.7 \\
\hline SSRIなL & SSRIあり & SSRIなL & SSRIあり & SSRIなL & SSRIあり \\
\hline-10 & -5 & -1.3 & +4.4 & 0 & +4.2 \\
\hline $\begin{array}{l}\text { 鼓膜換気 } \\
\text { チューブ } \\
\text { 留置なし }\end{array}$ & $\begin{array}{l}\text { 鼓膜換気 } \\
\text { チューブ } \\
\text { 留置あり }\end{array}$ & $\begin{array}{l}\text { 鼓膜換気 } \\
\text { チューブ } \\
\text { 留置なし }\end{array}$ & $\begin{array}{l}\text { 鼓膜換気 } \\
\text { チューブ } \\
\text { 留置あり }\end{array}$ & $\begin{array}{l}\text { 鼓膜換気 } \\
\text { チューブ } \\
\text { 留置なし }\end{array}$ & $\begin{array}{l}\text { 鼓膜換気 } \\
\text { チューブ } \\
\text { 留置あり }\end{array}$ \\
\hline-7.5 & +0.8 & -1.9 & +10.6 & +1.7 & +14.2 \\
\hline
\end{tabular}

\begin{tabular}{|c|c|c|c|c|c|c|c|c|c|c|c|c|c|c|c|c|c|}
\hline \multicolumn{6}{|c|}{$\begin{array}{l}\text { 低音域3周波数 (dB) } \\
(125,250,500 \mathrm{~Hz})\end{array}$} & \multicolumn{6}{|c|}{$\begin{array}{c}\text { 4分法 }(\mathrm{dB}) \\
(500,1000,2000,4000 \mathrm{~Hz})\end{array}$} & \multicolumn{6}{|c|}{$\begin{array}{c}\text { 高音域3周波数 }(\mathrm{dB}) \\
(2000,4000,8000 \mathrm{~Hz})\end{array}$} \\
\hline 20代 & 30代 & 40代 & 50代 & 60 代 & 70代 & 20代 & 30代 & 40代 & 50代 & 60代 & 70代 & 20代 & 30代 & 40代 & 50代 & 60 代 & 70代 \\
\hline-1.7 & -5.8 & -8.3 & -10 & -8.3 & +2.5 & +5 & -2.5 & -2.5 & -0.6 & +12.5 & +6.3 & +1.7 & +0.8 & +1.7 & +1.7 & +10 & +25.4 \\
\hline
\end{tabular}

\begin{tabular}{|c|c|c|c|c|c|c|c|c|c|c|c|}
\hline \multicolumn{4}{|c|}{$\begin{array}{l}\text { 低音域3周波数 (dB) } \\
(125,250,500 \mathrm{~Hz})\end{array}$} & \multicolumn{4}{|c|}{$\begin{array}{c}\text { 4分法 }(\mathrm{dB}) \\
(500,1000,2000,4000 \mathrm{~Hz})\end{array}$} & \multicolumn{4}{|c|}{$\begin{array}{c}\text { 高音域3周波数 (dB) } \\
(2000,4000,8000 \mathrm{~Hz})\end{array}$} \\
\hline$<500$ 日 & $<1000$ 日 & $<2000$ 日 & $\geqq 2000$ 日 & $<500$ 日 & $<1000$ 日 & $<2000$ 日 & $\geqq 2000$ 日 & $<500$ 日 & $<1000$ 日 & $<2000$ 日 & $\geqq 2000$ 日 \\
\hline-9.2 & -6.7 & -10 & +15 & -2.5 & +2.5 & 0 & +20 & -2.5 & +2.5 & +3.3 & +15 \\
\hline
\end{tabular}

$250,500 \mathrm{~Hz})$ および高音域周波数 3 分法 $(2000,4000,8000$ $\mathrm{Hz}$ )の中央值の変化（最終診察時聴力レベルの中央值一 初診時聴力レベルの中央值）を検討した（表 1)。2 群間 の検定には Mann-Whitney U 検定，3 群間以上の検定に はSteel-Dwass 法を用いた。
結果

\section{1. 性別と聴力変化}

年齢別の患者構成を図 1 に示す。年齢分布は 40 歳代 が最多であった。男女比は1：1.9で女性に多かった。 20 歳代から 40 歳代にかけて女性の割合が多くを占めた が，各年代で一定数の女性の症例を認めた。男性の割合 


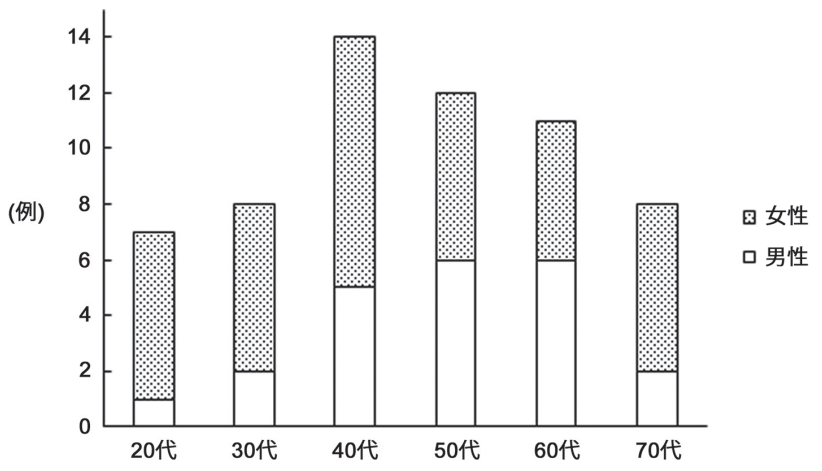

Fig. 1 Age distribution and sex ratio

There were 21 men and 39 women, with a male-to-female ratio of 1:1.9. The proportion of women was higher. Although women in their $20 \mathrm{~s}$ to $40 \mathrm{~s}$ accounted for a large proportion in the respective age groups, there were a certain number of women in each age group. The proportions of men increased in those in their 40s and older age groups. The proportions of men in their $50 \mathrm{~s}$ and $60 \mathrm{~s}$ were as high as those of women in the same age groups.

は 40 歳代から増加し始め, $50 \cdot 60$ 歳代では女性と同程 度の割合となった，男性と女性に扔ける聴力変化はそれ ぞれ，低音域 3 周波数：男性 $-6.7 \mathrm{~dB}$ ，女性 $-6.7 \mathrm{~dB}, 4$ 分法：男性 $-1.3 \mathrm{~dB}$ ，女性 $+1.3 \mathrm{~dB}$, 高音域 3 周波数：男 性 $+1.7 \mathrm{~dB}$ ，女性 $+3.3 \mathrm{~dB}$ であった。低音域周波数 3 分 法, 4 分法, 高音域周波数 3 分法の全ての聴力レベルの 変化に扔いて 2 群間で統計学的有意差は認めなかった。

\section{2. 年代と聴力変化}

各年代別における聴力変化を検討した。聴力変化はそ れぞれ, 低音域 3 周波数 : 20 歳代 $-1.7 \mathrm{~dB}, 30$ 歳代 -5.8 $\mathrm{dB}, 40$ 歳代 $-8.3 \mathrm{~dB}, 50$ 歳代 $-10.0 \mathrm{~dB}, 60$ 歳代 $-8.3 \mathrm{~dB}$, 70 歳代 $+2.5 \mathrm{~dB}, 4$ 分法: 20 歳代 $+5.0 \mathrm{~dB}, 30$ 歳代 -2.5 $\mathrm{dB}, 40$ 歳代 $-2.5 \mathrm{~dB}, 50$ 歳代 $-0.6 \mathrm{~dB}, 60$ 歳代 +12.5 $\mathrm{dB}, 70$ 歳代 $+6.3 \mathrm{~dB}$, 高音域 3 周波数 : 20 歳代 $+1.7 \mathrm{~dB}$,
30 歳代 $+0.8 \mathrm{~dB}, 40$ 歳代 $+1.7 \mathrm{~dB}, 50$ 歳代 $+1.7 \mathrm{~dB}, 60$ 歳代 $+10.0 \mathrm{~dB}, 70$ 歳代 $+25.4 \mathrm{~dB}$ であった. 全ての聴力 レベルの変化において各群間で統計学的有意差は認めな かった.

\section{3. 観察期間と聴力変化}

観察期間を500 日未満，500日以上 1000 日未満，1000 日以上 2000 日未満, 2000 日以上の 4 群に分けて, 各群 における聴力変化を比較した（図2）。聴力変化はそれ ぞれ, 低音域 3 周波数: 500 日未満 $-9.2 \mathrm{~dB}, 500$ 日以上 1000 日未満 $-6.7 \mathrm{~dB}, 1000$ 日以上 2000 日未満 $-10.0 \mathrm{~dB}$, 2000 日以上 $+15.0 \mathrm{~dB}, 4$ 分法 : 500 日未満 $-2.5 \mathrm{~dB}, 500$ 日以上 1000 日未満 $+2.5 \mathrm{~dB}, 1000$ 日以上 2000 日未満 0 $\mathrm{dB}, 2000$ 日以上 $+20.0 \mathrm{~dB}$, 高音域 3 周波数： 500 日未 満 $-2.5 \mathrm{~dB}, 500$ 日以上 1000 日未満 $+2.5 \mathrm{~dB}, 1000$ 日以 上 2000 日未満 $+3.3 \mathrm{~dB} ， 2000$ 日以上 $+15.0 \mathrm{~dB}$ であった。 4 分法掞よび高音域 3 周波数の聴力の変化に扔いて, 500 日未満の群と比較して 2000 日以上の群で有意に聴 力予後の悪化を認めた.

\section{4. ストレスの自覚の有無と聴力変化}

メニエール病の発症にはストレスが深く関与がする 5 . 本検討において，問診でストレスがあると回答した患者 は 52/60 例 (86.7\%) であった。 ストレスの内容では仕事 と回答した者が 32/60 例 (53.3\%) で最多，次いで家庭内 トラブルと回答した者は 24/60 例 (40.0\%) であった（重 複あり)。女性では仕事 $18 / 39$ (46.1\%), 家庭内トラブ ル 16/39 (41.0\%) は同等の割合であった。男性では仕事 14/21 (66.7\%), 家庭内トラブル 8/21 (38.1\%) であった。 女性では若年層から高齢層にかけて一定の割合で仕事, 家庭内のストレスを抱えていたが（20４0歳代：仕事 12/25 (48.0\%), 家庭内卜ラブル 11/25 (44.0\%), 50〜 70 歳 代：仕事 6/14 (42.3\%), 家庭内トラブル 5/14 (35.7\%)（重
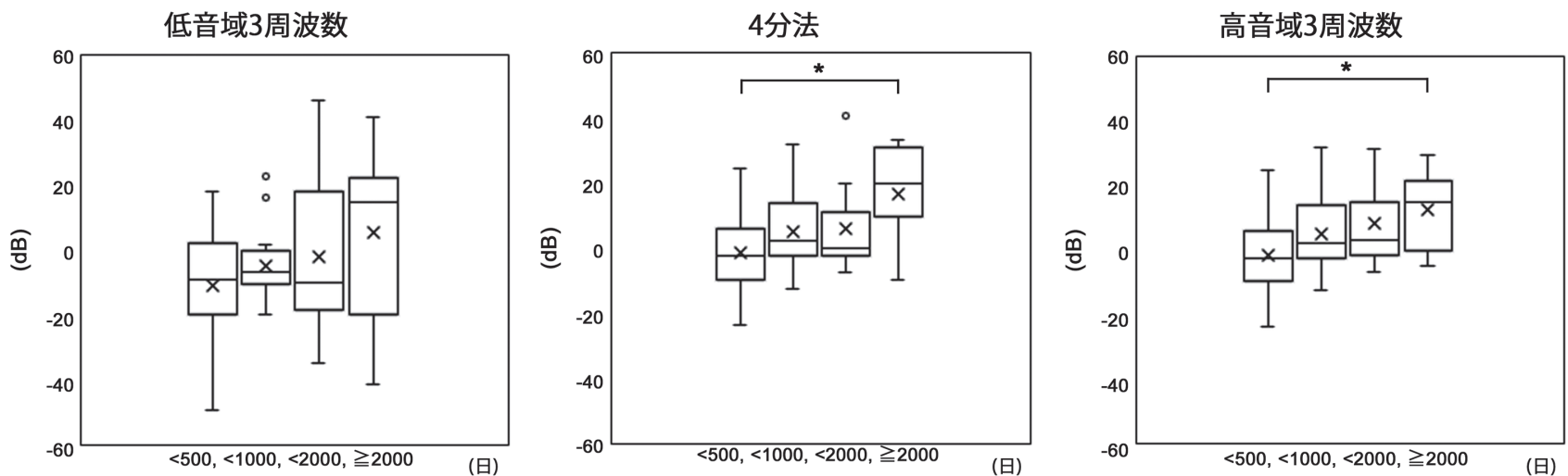

Fig. 2 Follow-up period and changes in auditory acuity

In terms of changes in auditory acuity calculated by the one-fourth method and determined in 3 high-frequency ranges, the outcomes of auditory acuity significantly worsened in the $\geq 2000$-day group than in the $<500$-day group $(* P<0.05)$. $(<500$-day group, $\mathrm{n}=20 ;<1000$ day group, $\mathrm{n}=18 ;<2000$-day group, $\mathrm{n}=11 ; \geq 2000$-day group, $\mathrm{n}=11)$. $\times$ : Mean, $\circ$ : Outlier. 

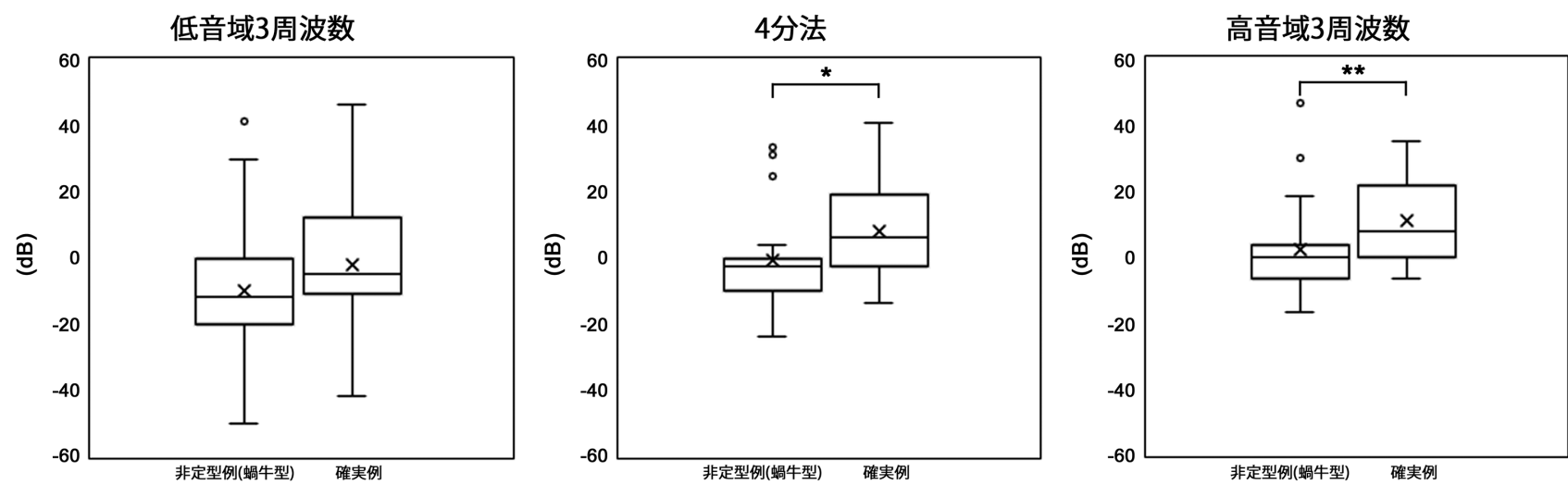

Fig. 3 Changes in auditory acuity in patients with definite Meniere's disease and those with atypical Meniere's disease (cochlear type)

In terms of changes in auditory acuity calculated by the one-fourth method and determined in 3 high-frequency ranges, the outcomes of auditory acuity significantly worsened in patients with definite Meniere's disease than in those with atypical Meniere's disease (cochlear type) $\left({ }^{*} P<0.05,{ }^{*} P<0.01\right)$. (patients with atypical Meniere's disease [cochlear type], $\mathrm{n}=19$; patients with definite Meniere's disease, $\left.\mathrm{n}=41\right)$ $\times$ : Mean, $\circ$ : Outlier.
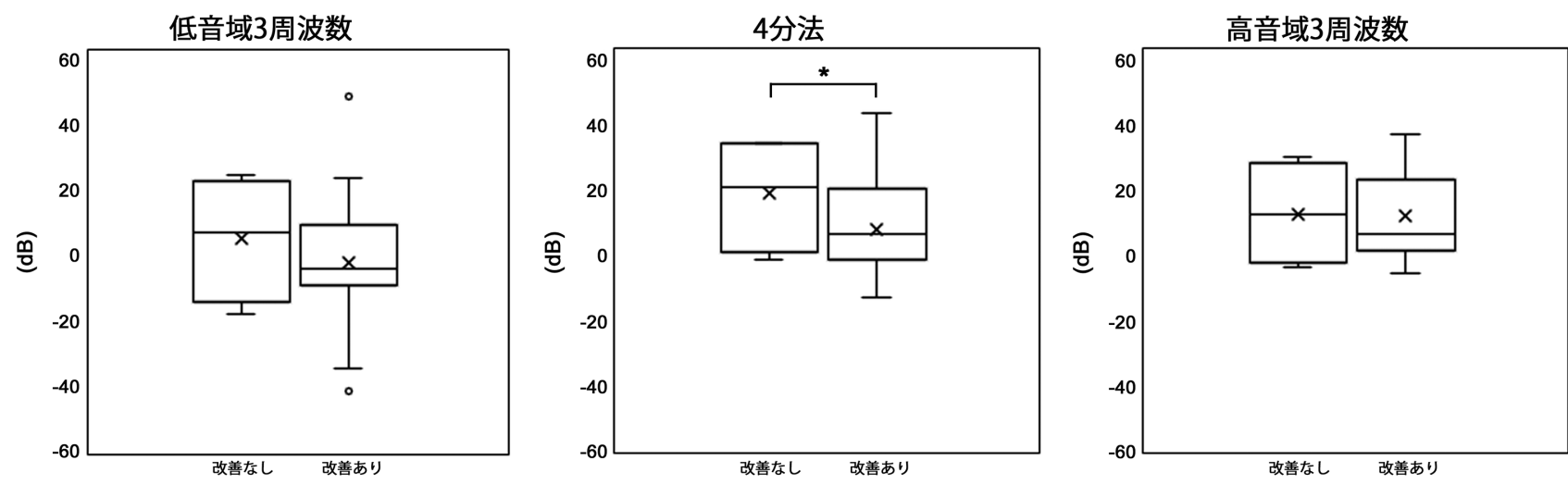

Fig. 4 Changes in auditory acuity in patients with and without improvement in dizziness

In terms of auditory acuity calculated by the one-fourth method, the outcomes of auditory acuity significantly worsened in patients without improvement in dizziness than in those with improvement $\left({ }^{*} P<0.05\right)$. (patients without improvement in dizziness, $\mathrm{n}=5$; patients with improvement in dizziness, $\mathrm{n}=36$ ). $\times$ : Mean, $\circ$ : Outlier.

複あり)，男性では若年層では仕事によるストレスが 多く（20４0 代：仕事 10/16 (62.5\%), 家庭内トラブル $5 / 16(31.3 \%)$ (重複あり)), 高齢になるにつれて家庭内 ストレスが増加した $(50 \sim 70$ 代：仕事 3/5 (60.3\%), 家 庭内トラブル $4 / 5(80.0 \%)$ （重複あり））。スレスの自覚 の有無別の聴力変化は, 低音域 3 周波数 : ストレスなし $-0.8 \mathrm{~dB}$, ストレスあり $-7.5 \mathrm{~dB}, 4$ 分法：ストレスなし $+3.1 \mathrm{~dB}$ ，ストレスあり $0 \mathrm{~dB}$, 高音域 3 周波数 : ストレ スなし $+3.3 \mathrm{~dB}$ ，ストレスあり $+1.7 \mathrm{~dB}$ で， 2 群間で統計 学的有意差は認めなかった。

\section{5. めまい症状と聴力変化}

メニエール病長期観察症例におけるめまい症状の有無 別の聴力変化を検討するために，メニエール病確実例と メニエール病非定型例（螖牛型）を比較した（図 3). 聴力変化はそれぞれ, 低音域 3 周波数 : 非定型例（螖牛 型） $-14.2 \mathrm{~dB}$, 確実例 $-5.0 \mathrm{~dB}, 4$ 分法: 非定型例（蝸牛
型） $-3.1 \mathrm{~dB}$ ，確実例 $+5.0 \mathrm{~dB}$ ，高音域 3 周波数 : 非定型 例 (蝸牛型) $0 \mathrm{~dB}$ ，確実例 $+11.7 \mathrm{~dB}$ であった。 4 分法お よび高音域 3 周波数の聴力レベルの変化において, メ二 エール病非定型例（蝸牛型）と比較してメニエール病確 実例で有意に聴力予後の悪化を認めた。

メニエール病確実例のうち，めまい症状改善の有無別 に聴力変化を検討した（図 4). めまい症状の評価はめ まい発作回数が受診前より明瞭に減少したものを改善あ りとした，聴力変化はそれぞれ，低音域 3 周波数 : めま い症状改善なし $+5.8 \mathrm{~dB}$, めまい症状改善あり $-5.0 \mathrm{~dB}$, 4 分法：めまい症状改善なし $+19.4 \mathrm{~dB}$, めまい症状改 善あり $+5.0 \mathrm{~dB}$, 高音域 3 周波数：めまい症状改善なし $+10.8 \mathrm{~dB}$, めまい症状改善あり $+5.0 \mathrm{~dB}$ であった. 4 分 法の聴力レベルにおいて，めまい症例改善ありの群と比 較してめまい症状改善なしの群で有意に聴力予後の悪化 を認めた。 

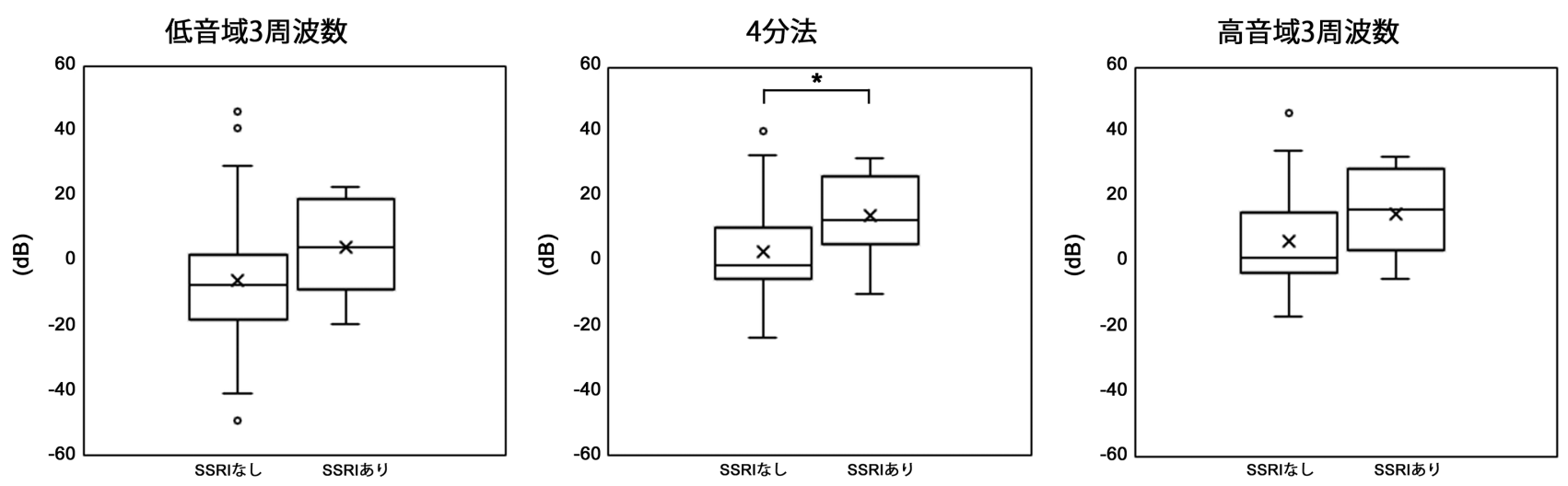

Fig. 5 Changes in auditory acuity in patients treated with and without selective serotonin reuptake inhibitors

In terms of auditory acuity calculated by the one-fourth method, the outcomes significantly worsened in patients treated with selective serotonin reuptake inhibitors (SSRIs) $(* P<0.05)$. (patients treated without SSRIs, $\mathrm{n}=50$; patients treated with SSRIs, $\mathrm{n}=10$ ). $\times$ : Mean, ०: Outlier.

\section{6. 治療と聴力変化}

当科ではメニエール病患者全例に認知行動療法を行 い,さらに各症例に応じて漢方薬，イソソルビド，抗不 安薬，SSRI の投与，鼓膜換気チューブ留置術などを併 用して行っている.内リンパ水腫の改善目的に浸透圧利 尿剂としてイソソルビドが投与された，漢方薬（五苓散 または苓桂尤甘湯）は主にめまい症状を伴う症例に対し て, 抗不安薬（クロチアゼパム, エチゾラム, ジアゼパ ム、ロフラゼプ酸エチルまたはタンドスピロン) は不安 要素が強い症例に対して, SSRI（パロキセチンまたは フルボキサミン）は抑うつ傾向の強い症例に対して投与 された。保存的加療のみでめまい症状のコントロールが 難しい症例に対しては鼓膜換気チューブ留置術が行われ た，漢方薬は 38 例，イソソルビドは 34 例，抗不安薬は 14 例，SSRI は 10 例に投与された（重複あり）。鼓膜換 気チューブ留置術は 22 例に施行されていた。各治療の 有無に扔ける聴力変化を検討した。

漢方薬投薬の有無に㧍ける聴力変化はそれぞれ，低音 域 3 周波数: 漢方薬なし $-10.0 \mathrm{~dB}$, 漢方薬あり $-5.0 \mathrm{~dB}$, 4 分法: 漢方薬なし $-1.3 \mathrm{~dB}$, 漢方薬あり $+4.4 \mathrm{~dB}$, 高音 域 3 周波数: 漢方薬なし $0 \mathrm{~dB}$, 漢方薬あり $+4.2 \mathrm{~dB}$ で あった，それぞれの聴力レベルの変化において漢方薬有 無の 2 群間で統計学的有意差は認めなかった、イソソル ビド投薬の有無における聴力変化はそれぞれ，低音域 3 周波数：イソソルビドなし $-10.0 \mathrm{~dB}$ ，イソソルビドあ り $-5.0 \mathrm{~dB}, 4$ 分法：イソソルビドなし $-1.3 \mathrm{~dB}$, イソソ ルビドあり $+4.4 \mathrm{~dB}$, 高音域 3 周波数：イソソルビドな し $0 \mathrm{~dB}$ ，イソソルビドあり $+4.2 \mathrm{~dB}$ であった。 それぞれ の聴力レベルの変化に扔いてイソソルビド有無の 2 群間 で統計学的有意差は認めなかった，抗不安薬の有無にお ける聴力変化はそれぞれ，低音域 3 周波数：抗不安薬な し $-6.7 \mathrm{~dB}$, 抗不安薬あり $-5.8 \mathrm{~dB}, 4$ 分法: 抗不安薬な L $-2.5 \mathrm{~dB}$, 抗不安薬あり $+2.5 \mathrm{~dB}$, 高音域 3 周波数 : 抗
不安薬なし $+5.0 \mathrm{~dB}$, 抗不安薬あり $+1.7 \mathrm{~dB}$ であった. それぞれの聴力レベルの変化に抒いて抗不安薬有無の 2 群間で統計学的有意差は認めなかった. SSRIの有無に おける聴力変化はそれぞれ，低音域 3 周波数：SSRI な し $-10.0 \mathrm{~dB}$, SSRI あり $-5.0 \mathrm{~dB}, 4$ 分法：SSRI なし -1.3 $\mathrm{dB}, \mathrm{SSRI}$ あり $+4.4 \mathrm{~dB}$, 高音域 3 周波数：SSRI なし 0 $\mathrm{dB} ， \mathrm{SSRI}$ あり $+4.2 \mathrm{~dB}$ であった（図 5). 4 分法の聴力 レベルの変化に抒いて，SSRI 投与ありの群で有意に悪 化を認めた，鼓膜換気チューブ留置術の有無における聴 力変化はそれぞれ，低音域 3 周波数：鼓膜換気チューブ 留置なし $-7.5 \mathrm{~dB}$, 鼓膜換気チューブ留置あり $+0.8 \mathrm{~dB}$, 4 分法: 鼓膜換気チューブ留置なし $-1.9 \mathrm{~dB}$, 鼓膜換気 チューブ留置あり $+10.6 \mathrm{~dB}$, 高音域 3 周波数 : 鼓膜換気 チューブ留置なし $+1.7 \mathrm{~dB}$, 鼓膜換気チューブ留置あり $+14.2 \mathrm{~dB}$ であった（図 6). 4 分法の聴力レベルの変化に おいて, 鼓膜換気チューブ留置術ありの群で有意に聴力 予後の悪化を認めた。

\section{考察}

メニエール病や急性低音障害型感音難聴の病態は内リ ンパ水腫と考えられている。急性低音障害型感音難聴で 難聴を反復する症例はメニエール病非定型例（蝸牛型） に包括される。メニール病非定型例（蝸牛型）の中に はメニエール病確実例へ移行する症例もある。メニエー ル病の問題点の一つとして, 病期の進行により不可逆性 の難聴の進行がみられ聴力の長期予後が不良であること である。当科ではメニエール病患者に対して投薬治療と ともに認知行動療法と有酸素運動を含めた生活指導を 行っているが，難聴のコントロールが困難な症例が散見 される。メニエール病による難聴・めまいの発作頻度や 発症間隔，治療に対する反応は多様であり，聴力予後の 予測は難しい．聴力変化の指標となる要因が明らかにな れば，聴力予後を予測するうえでの有用性は大きいと考 
低音域3周波数

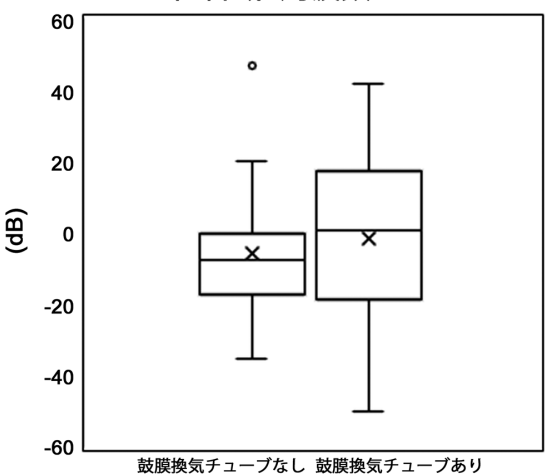

4分法

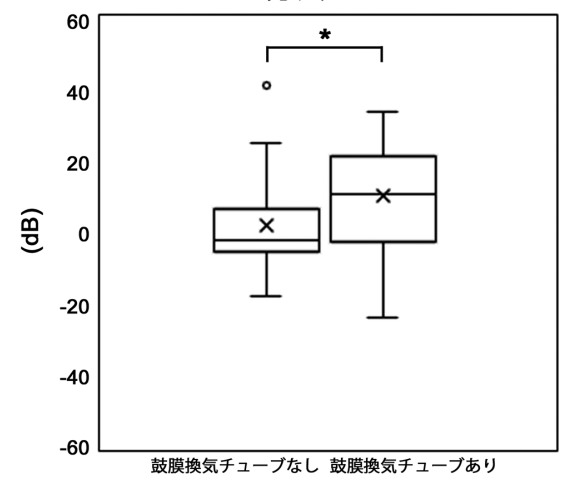

高音域3周波数

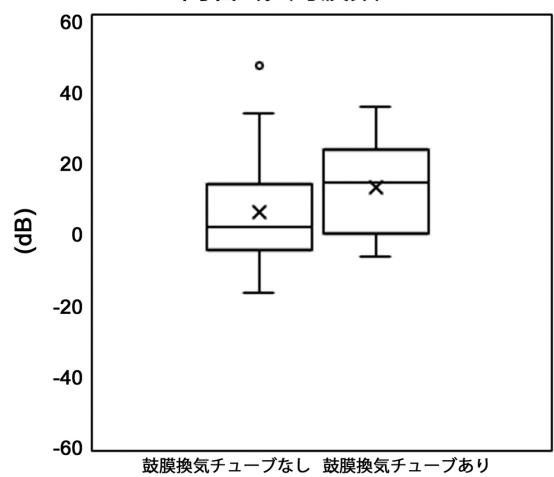

Fig. 6 Changes in auditory acuity in patients treated with and without ventilation tube insertion

In terms of auditory acuity calculated by the one-fourth method, the outcomes of auditory acuity significantly worsened in patients treated with ventilation tube insertion $(* P<0.05$ ). (patients treated without ventilation tube insertion, $\mathrm{n}=38$; patients treated with ventilation tube insertion, $\mathrm{n}=22)$. $\times$ : Mean, o: Outlier.

える. 今回, 長期に経過を観察し得たメニエール病症例 で聴力子後に影響する因子を後ろ向き研究で検討した。 本検討におけるメニエール病長期観察症例の内訳はメ ニエール病確実例 41 例, メニエール病非定型例（螖牛 型） 19 例で, その比は 2.2:1 であった。過去の報告で はメニエール病非定型例（蝸牛型）の頻度はメニエール 病確実例の約 $1 / 2$ とされており ${ }^{6}$, 本検討においてもそ の頻度は一致した。男女比は 1：1.9 で女性に多く, 年 代では 40 歳代が最も多かった。近年ではメニエール病 は女性が男性の 1.5〜2 倍多いとされており ${ }^{7,8)}$, 本検討 においても同様の傾向にあった. 1960～70 年代はメ二 エール病患者の男女比に差はなかったが，その後女性患 者の割合は増加している ${ }^{9,10)}$ 。本検討においては 20〜40 歳代における女性の占める割合が多いが, 全ての年代 において一定数の女性の症例を認めた。一方, 男性で は 40〜60 歳代に多く認められた。これらの傾向の背景 として女性の場合には女性の社会進出による職場や育児 の問題, 男性の場合には仕事・職場での問題, 男女共通 のものとして高齢化による介護の問題や家庭内の問題と いった環境要因など, 我が国における社会や家庭環境の 変化が影響していると考えられる ${ }^{7,8)}$. メニエール病の 発症にはストレスが深く関与することが知られている5 実際に本検討において，問診でストレスがあると回答し た患者は $86.7 \%$ と多く，女性では全年代において一定 の割合で仕事, 家庭内のストレスが認められた。男性で は若年層で仕事によるストレスが多く, 高齢になるにつ れて家庭内ストレスが増加していた。このような職場や 家庭内の問題は容易には解決することができないので病 悩期間も長期化すると考えられる。本検討においては性 別および年代別では聴力変化に有意差は認められず，聴 力予後に影響を与える因子ではなかった。 ストレスの自 覚の有無では聴力変化に差がなかったが, 本検討におい ては問診によるストレスの自覚の確認のみであるので,
患者本人の過剩適応によりストレスの自覚がない可能性 も否定できない。今後は質問紙法などを用いたストレス 評価を基に聴力変化を検討したい。観察期間別に聴力変 化を検討してみると，観察期間が 2000 日以上に及ぶ症 例では 500 日未満の症例と比較して有意に中〜高音域周 波数の聴力の悪化を認めた。メニエール病の病態は内リ ンパ水腫と考えられているが現在もなお詳細については 解明されていない点が多い. 血管条で分泌された内リン パ液の吸収部位である内リンパ管や喠の機能低下から内 リンパ腔に液が過剰に貯留して内リンパ水腫が形成され ると考えられる ${ }^{10)}$. 近年では水代謝の観点から内リンパ 水腫と抗利尿ホルモンの関連性が研究されている ${ }^{11-13)}$.

内リンパ水腫の病態は早期には低音障害をきたし, 再発 を繰り返す度に内耳の器質的変化をきたして徐々に高音 障害をきたすと考えられている1．コントロール不良な 症例が長期化するわけであるから，経過観察期間が長期 に及ぶ症例の聴力レベルがそうでない症例と比較して悪 化を示すことが予測されるが，本検討の結果からも病態 の長期化とともに高音域の聴力悪化の進行が再確認され た。また，経過観察期間 2000 日以上というのが一つの 指標になった。

めまい症状の有無は聴力予後に影響するかを検討する ために，めまい症状を伴うメニエール病確実例とめまい 症状を伴わないメニエール病非定型例（螖牛型）の聴力 変化を比較検討した. 4 分法および高音域 3 周波数の聴 カレベルの変化において, メニエール病確実例はメ二 エール病非定型例（蝸牛型）と比較して有意に聴力予後 は悪かった。めまい症状の有無は中〜高音域の聴力に影 響を与え，聴力予後を予測するうえでの指標になると考 えられる。前述したようにメニエール病の病態は内リン パ水腫と考えられているが, どのような機序で形成さ れ，またこれがどのようにめまい発作を引き起こすのか は未だに明らかにされていない。仮説の一つとして「膜 
迷路破裂説」がある ${ }^{10)}$ ．これは伸展した螖牛の膜迷路が 破裂し, カリウムに富む内リンパ液が外リンパ液に漏出 することによって前庭神経が刺激されてめまい症状を呈 するというものである。この仮説に基づくと，内リンパ 腔の軽度の拡張のみの水腫ではめまい症状は呈さず，ラ イスネル膜が破裂するほどの強い水腫を引き起こす負荷 が螖牛内リンパ腔にかかった際にめまいを呈すると考え られる。過去の報告では，MRI 検査による内リンパ水 腫の評価において前庭症状を伴わないメニエール病非定 型例（蝸牛型）は蝸牛内リンパ水腫のみが生じているわ けでなく，前庭にも内リンパ水腫が生じていることが確 認されている ${ }^{14)}$ 。つまり，めまい発作を繰り返す度に蝸 牛の内リンパ腔へ強い負荷がかかり，蝸牛への障害が大 きくなるので，病悩期間が長期化した場合にはメニエー ル病確実例はメニエール病非定型例（蝸牛型）と比較し て聴力予後は悪化することになると推測することができ る。一方で，メニエール病確実例におけるめまい症状の 改善の有無と聴力変化との検討では，めまい症状の改善 なしの群において有意に 4 分法聴力の聴力予後の悪化を 示した。また，保存的治療のみでめまい症状のコント ロールが不良な症例に対して鼓膜換気チューブ留置術が 施行されているが，鼓膜換気チューブ留置術が施行され ている群は留置術が施行されていない群と比較して有意 に4 分法聴力の聴力予後の悪化を示した。これは鼓膜換 気チューブ留置術を施行されている症例がメニエール病 重症例であるからと考えられる。これらの結果からも， めまい症状を呈する症例は内リンパ水腫により蝸牛への 負担が大きい可能性があると考える。

投薬治療別の聴力予後の検討では, SSRI を投与され ている症例では中音域周波数の聴力予後は有意に悪かっ た。これは鼓膜換気チューブ留置術を施行されている症 例と同様にSSRIを投与されている症例はメニエール病 重症例であるためと考えられる。古くからメニエール病 にうつなどの心因的要因が強く関連することが知られて いる。うつ状態ではシナプス間隙でのセロトニン濃度が 低下しているという仮説がある(セロトニン仮説 $)^{15)}$. セロトニン濃度の低下によってめまい症状が生じるとさ れる ${ }^{16)}$ 。当科ではメニエール病全例に対して認知行動療 法や生活指導を行っているが，抑うつ傾向が強い症例に 対してはSSRI が投与されている. SSRI であるパロキセ チンは海馬に存在する平衡感覚に関与するセロトニン作 動性神経細胞におけるセロトニン再吸収阻害や ${ }^{17)}$ 前庭神 経核に投射するセロトニン作動性神経に直接作用すると 考えられており ${ }^{18)}$ ，メニエール病のめまい発作を有意に 改善させる ${ }^{19)}$ 。一方で，中枢聴覚伝導路である中脳下丘 や上オリーブ核にセロトニントランスポーターが存在し, セロトニンの機能異常で聴覚過敏や耳鳴が生じる誘発す るといわれている20). これに作用して SSRI が耳鳴に対 して有効性を示すとされているが21)，メニエール病患者
における聴力改善の有効性は示されていない ${ }^{19)}$ 。また, メニエール病患者ではセロトニンの代謝物質であるメ ラトニンの分泌が久そしているという報告がある ${ }^{22,23)}$. 分子生物学的な研究から下垂体後葉から分泌されるバソ プレシンの分泌の増加は内リンパ水腫の形成を誘発する といわれており ${ }^{11,12)}$ ，メラトニンはこのバソプレシンの 分泌を阻害する。うつ状態になりセロトニン濃度が低下 するとバソプレシン分泌の抑制が解除されて内リンパ水 腫が生じやすくなる可能性はある。そのため, SSRIが 投与されるような抑うつ傾向の強い症例では聴力予後が 悪い傾向がみられるのかもしれない。しかし，内リンパ 水腫はメニエール病の病理組織学的な結果であるとする 報告がある一方で ${ }^{24)}$ ，早期のメニエール病においても内 リンパ水腫が確認されることから内リンパ水腫は結果で はないとする報告もあり ${ }^{25)}$, 今後更なるメニエール病の 病態の解明が望まれる。

\section{まと め}

1. 1 年以上加療したメニエール病症例 60 例の背景因子 と聴力予後を検討した。

2. メニエール病長期観察症例は女性に多く，40歳代に ピークを認めた

3. 経過観察期間が 2000 日以上に及ぶ症例では 500 日未 満の症例と比較して, 中〜高音域周波数の聴力予後 は有意に悪かった。

4. メニエール病確実例ではメニエール病非定型例（蝸 牛型）と比較して中〜高音域周波数の聴力予後は有 意に悪かった。

5. めまい症状改善なしの症例は改善ありの症例と比較 して中音域周波数の聴力予後は有意に悪かった。

6. 鼓膜換気チューブ留置術，SSRI を投与されている症 例は重症例であると考えられ，鼓膜換気チューブ留 置術，SSRI を投与されていない症例と比較して中音 域周波数の聴力予後は有意に悪かった。

利益相反に該当する事項はない.

\section{文献}

1）高橋正紘, 大貫純一, 小田桐恭子, 他. 内リンパ水腫 の聴力変動に見られる規則性. Otology Japan 2003; 406: 135-140.

2) Friberg U, Stahle J, Svedberg A. The natural course of Meniere's disease. Acta Otolaryngol Suppl 1984; 406: 72-77.

3) 診断基準化委員会 : めまいの診断基準化のための資料 診断基準 2017 年改定. Equilibrium Res 2017; 76: 233-241.

4) Committee on Hearing and Equilibrium. Guidelines for the diagnosis and evaluation of therapy in Meniere's disease. Otolaryngol Head Neck Surg 1995; 113: 181-185.

5）厚生労働省難治性疾患克服研究事業 前庭機能異常に関 する調査研究班：メニエール病診療ガイドライン 2011 年版. 金原出版株式会社, 東京, 2011; 8-11.

6）肥塚 泉。急性期の治療法. 高橋晴雄 編. ENT 臨床フ 
ロンティア「急性難聴の鑑別とその対処法」. 中山書店, 東京, 2014; 183-188.

7）高橋正紘.メニエール病患者にみられる行動習慣の特 徵。高橋晴雄 編.「めまい診療のコツと落とし穴」.中山 書店, 東京, 2005; 114-115.

8）高橋正紘. 生活習慣・ストレスの関与（メニエール病）. Equilibrium Res 2008; 67: 213-221.

9）水越鉄理, 將積日出夫, 渡辺行雄. メニエール病の疫学 一本邦の調査研究を中心に一. Equilibrium Res 1997; 56: 219-233.

10）矢沢代四郎．めまい・平衡障害をきたす疾患の概観．め まい平衡医学会 編.「イラスト」めまいの検査 改訂第 2 版。診断と治療社, 東京, 2009; 108-109.

11）長沼英明. メニエール病と Vasopressin 系. Equilibrium Res 2013; 72: 259-267.

12) 北原 糺. メニエール病におけるストレス・ホルモンと 内リンパ囊・水代謝. Equilibrium Res 2013; 72: 268-273.

13）柿木章伸. 内リンパ水腫形成における抗利尿ホルモンと 水チャネルの役割. Equilibrium Res 2013; 72: 274-279.

14）曾根三千彦. 内リンパ水腫一画像評価とその意義一. Equilibrium Res 2015; 74: 303-307.

15）原井宏.【うつ病のすべて】精神療法・他うつ病の治療 と医療の近年の発展と最近の論議 治療法の選択を決め るもの. 医のあゆみ 2006; 219: 979-983.

16）五島史行. 治療のポイント 薬物療法に併用可能な非薬 物療法. Equilibrium Res 2014; 73: 229-234.

17) Gavrilov VV, Wiener SI, Berthoz A. Whole body rotations enhance hippocampal theta rhythmic slow activity in awake rats passively transported on a mobile robot. Ann N Y Acad Sci 1996; 781: 385-398.

18) Inoue $S$, Kita $T$, Yamanaka $T$, et al. Measurement of 5-hydroxytryptamine release in the rat medial vestibular nucleus using in vivo microdialysis. Neurosci Lett 2002; 323: 234-238.

19）瀧 正勝, 長谷川達央, 坂口博史, 他. 精神疾患を伴っ たメニエール病に対する塩酸パロキセチンによる治療経 験. Equilibrium Res 2013; 72: 171-175.

20）君付 隆, 松本 希, 高岩一貴, 他. 聴力に異常のない 聴覚過敏患者に打注僟能検査の特徵. Audiology Japan 2009; 52: 152-156.

21）小原修幸，武市紀人，福田 諭。耳鳴に対する SSRI（選 択的セロトニン再取り込み阻害薬）の治療効果に関する 検討. Audiology Japan 2011; 54: 327-328.

22) Aoki M, Yokota Y, Hayashi T, et al. Disorder of the saliva melatonin circadian rhythm in patients with Meniere's disease. Acta Neurol Scand 2006; 113: 256-261.

23）山寺博史. 睡眠障害のトピックス：睡眠・覚醒リズム障 害ついて. J Nippon Med Sch 2001; 68: 344-348.

24) Merchant SN, Adams JC, Nadol JB Jr. Pathophysiology of Meniere's syndrome: are symptoms caused by endolymphatic hydrops? Otol Neurotol 2005; 26: 74-81.

25) Foster CA, Breeze RE. Endolymphatic hydrops in Ménière's disease: cause, consequence, or epiphenomenon? Otol Neurotol 2013; 34: 1210-1214. 